\title{
IMPLEMENTASI PENYUSUNAN LAPORAN KEUANGAN BERDASARKAN SAK EMKM PADA UMKM PASTELLIA INTERMODA BUMI SERPONG DAMAI DENGAN MENGGUNAKAN APLIKASI SI APIK PERIODE 2018 - 2019
}

\author{
Bettynia Dwi Orparani \\ Institut Teknologi Dan Bisnis Ahmad Dahlan Jakarta \\ e-mail: bettynia31@gmail.com \\ Yumniati Agustina \\ Institut Teknologi Dan Bisnis Ahmad Dahlan Jakarta \\ e-mail: yumniatiagustina@itb-ad.ac.id.
}

\begin{abstract}
The purpose of this study is to evaluate whether the financial statements based on SAK EMKM have been applied by Pastellia Intermoda Bumi Serpong Damai SMEs, compare the financial statements of Pastellia Intermoda Bumi Serpong Damai SMEs with Si Apik's version of the financial statements, and interpret the results of a comparative analysis which is then drawn into a conclusion. . This research method is a comparative \& descriptive method. Data obtained through interviews, observation. Comparative analysis of the data by analyzing the presentation of the financial statements of Pastellia Intermoda Bumi Serpong Damai SMEs with a theory that refers to the Financial Accounting Standards for Micro, Small and Medium Entities (SAK EMKM) and comparing financial statements manually with financial reports using the Si Apik application. The results of this study are that the types of financial statements produced are statement of financial position (balance sheet), income statement and cash flow statement, and do not make notes on financial statements (CALK) so that they are not in accordance with $S A K$ EMKM. The difference between the financial statements produced by Pastellia Intermoda Bumi Serpong SMEs and the Si Apik application is in the statement of financial position and income statement related to depreciation of fixed assets.
\end{abstract}

Keywords: EMKM Finansial Accounting Standards, MSMEs, Si Apik

\section{PENDAHULUAN}

Usaha Mikro, Kecil dan Menengah memiliki peran penting dalam pembangunan ekonomi nasional serta dalam penyerapan ketenagakerjaan. UMKM juga dapat menjadi contoh usaha kecil yang dapat berkembang dengan pesat jika 
dalam pengelolaan baik dan benar.. Dan banyak UMKM yang kurang berkembang karna memiliki masalah dalam permodalan karena tidak adanya penjamin atau kurang terpenuhinya syarat untuk dapat mengajukan pinjaman kepada kreditur (perbankan). Banyak UMKM terkadang pemilik usahanya tidak memahami arus perdagangan dalam usahanya seperti pembelian, penjualan, persediaan bahkan laporan keuangan yang dihasilkan Sehingga banyak UMKM yang baru saja berdiri lalu bangkrut atau mati.

UMKM memiliki standar dalam penyusunan laporan keuangannya yang disebut Standar Akuntansi Keuangan Entitas Mikro Kecil dan Menengah. Yang mana SAK EMKM tersebut dapat membantu penyusunan laporan keuangan untuk pendiri usaha lebih mudah dalam memahami arus perdagangan yang terjadi dalam usahanya khususnya dari sisi laporan keuangan yang dibuat.

Penyusunan laporan keuangan berdasarkan SAK EMKM memang belum banyak yang mengikuti atau menerapkan. Karena banyaknya masyarakat biasa atau awam yang belum memahami tentang pencatatan laporan keuangan UMKM yang baik dan benar. Sehingga mereka hanya asal mendirikan UMKM tanpa memperhatikan aspek lain yang dapat berpengaruhi dalam kemajuan usahanya tersebut.

Sholikin \& Setiawan (2018) mengemukakan bahwa UMKM di Kabupaten Blora yaitu ketidaksiapan dalam mengimplementasikan SAK EMKM pada Usaha Rumah Mode Een Productions dan Kanaya Konveksi karena tidak mengetahui tentang adanya SAK EMKM, dalam pencatatan masih berbasis kas, belum adanya SDM yang memahami tentang penyusunan laporan keuangan

Hasil penelitian Judianto, dkk (2018) menunjukkan bahwa UKM Décor Surakarta belum melakukan pencatatan laporan keuangan dengan baik sesuai dengan SAK EMKM. Adapun kendala-kendala yang dialami Davin Decor Surakarta seperti masih menggunakannya proses pencatatan legacy atau manual dan media penyimpanan atau filling data keuangan masih tradisional. Amatullah, dkk (2019), menunjukkan Batik Jumput Dahlia belum menyusun laporan keuangan berdasarkan SAK EMKM, karena UMKM Batik Jumput Dahlia tidak mempunyai laporan keuangan. 
Selain dari penyusunan laporan keuangan berdasarkan SAK EMKM penulis juga akan menyajikan aplikasi yang dapat digunakan pemilik UMKM untuk dapat menyusun laporan keuangan secara langsung sehingga dapat memudahkan dalam analisa perkembangan usahanya serta dapat digunakan untuk mengajukan modal kepada kredit (perbankan). Aplikasi tersebut adalah Aplikasi Si Apik yang merupakan sebuah sistem keuangan bebasis android mulai dari pencatatan, proses akuntansi hingga penyusunan laporan keuangan yang dapat digunakan untuk meyusun laporan keuangan dalam UMKM.

Penelitian tentang aplikasi Si Apik yang dilakukan oleh Bayu Wiratman, dkk (2019), menunjukkan bahwa program pengabdian ini berhasil meningkatkan pemahaman dasar-dasar pembukuan keuangan dan meningkatkan pemahaman \& ketrampilan dalam penggunaan aplikasi berbasis android "Si Apik". Penelitian yang dilakukan oleh Mukhzarudfa \& Kusumastutu (2019), menunjukkan bahwa belum ada satupun yang membuat pencatatan dan penyusunan laporan keuangan dengan menggunakan suatu sistem informasi. Oleh karena itu perlu adanya aplikasi “Si Apik"guna menunjang penyusunan laporan keuangan tersebut. Penelitian yang dilakukan oleh Muhammad Tajibu, dkk (2019), menunjukkan bahwa kebanyakan UMKM dalam pelaksanaan pengelolaan laporan keuangannya belum memiliki sumber daya yang cakap, sehingga untuk memudahkan pelaporan diperlukan pelatihan UMKM untuk mengakses aplikasi "Si Apik".

Agustina, dkk (2021) mengadakan pelatihan penyusunan laporan keuangan dengan menggunakan aplikasi Si Apik berbasis android di masa pandemi Covid 19, dilakukam melalui acara webinar melalui Zoom Meeting. Pelatihan diberikan dalam bentuk ceramah, tanya jawab, studi kasus dan demonstrasi. Narasumber mendemonstrasikan secara detail langkah demi langkah mulai dari melakukan instalasi, inisialisasi data usaha, input data saldo awal, input transaksi, hingga pembuatan laporan keuangan. Para peserta mengikuti proses tersebut langsung pada perangkat android masing-masing. Dengan memberikan pelatihan ini diharapkan dapat memberikan manfaat kepada UMKM diantaranya: pelaku UMKM mampu mencatat transaksi keuangan secara terkomputerisasi, serta menyusun laporan keuangan berdasarkan SAK EMKM dengan menggunakan aplikasi SI APIK, 
UMKM Pastellia yatu usaha mikro, kecil dan menengah yang bertempat di Pasar Modern Intermoda Bumi Serpong Damai, Tangerang Selatan. UMKM Pastellia merupakan sebuah usaha yang bergerak dalam bidang perdagangan yaitu membeli barang jadi lalu dijual kembali. Laporan keuangan yang dibuat oleh UMKM Pastellia Intermoda BSD sangatlah sederhana. Hanya sebatas pencatatan penerimaan dan pengeluaran kas yang menghasilkan laporan keuangan sederhana yang sistem pencatatannya masih bersifat manual. Sehingga UMKM Pastellia ingin mencoba menggunakan Aplikasi Si Apik untuk penyusunan laporan keuangannya agar lebih cepat dan mudah dan berstandar SAK EMKM.

\section{Permasalahan}

Adapun permasalahan yang dihadapi UMKM Pastellia Intermoda BSD adalah sebagai berikut:

1. Bagaimana penyajian laporan keuangan yang diterapkan UMKM Pastellia Bumi Serpong Damai dan kesesuaiannya dengan SAK EMKM?

2. Bagaimana penyusunan laporan keuangan dengan menggunakan aplikasi SIAPIK pada UMKM Pastellia Bumi Serpong Damai?

3. Bagaimana perbedaan penyajian laporan keuangan UMKM Pastellia Bumi Serpong secara manual dan dengan menggunakan aplikasi Si Apik?

\section{Tujuan}

Tujuan penelitian ini ialah:

1. Untuk mengkaji bagaimana pelaporan keuangan yang diterapkan UMKM Pastellia Bumi Serpong Damai,

2. Menyusun laporan keuangan dalam aplikasi SIAPIK pada UMKM Pastellia Bumi Serpong Damai,

3. mengevaluasi perbedaan penyajian laporan keuangan UMKM Pastellia Bumi Serpong secara manual dan dengan menggunakan aplikasi Si Apik?

\section{LANDASAN TEORI}

\section{Laporan Keuangan}

Menurut Hery (2015:18), menyatakan "produk akhir dari proses pencatatan dan pengikhtisaran sebuah data suatu transaksi bisnis disebut laporan keuangan”. 
Laporan keuangan adalah alat untuk menghubungan data keuangan suatu entitas bagi yang membutuhkan.

Menurut Zamzami (2017:98), pada umumnya laporan keuangan yang disiapkan oleh perusahaan terdiri atas:

a. Laporan posisi keuangan

Merupakan gambaran posisi keuangan tentang aktiva, hutang dan modal.

b. Laporan laba rugi

Berisi informasi tentang pendapatan dengan biaya dalam perusahaan yang ada selama periode waktu tertentu.

c. Laporan perubahan modal.

Memaparkan perubahan ekuitas pemilik untuk jangka waktu tertentu.

d. Laporan arus kas

Menyajikan penggunaan kas (uang cash) masuk dan keluar dalam perusahaan selama satu periode.

e. Catatan atas laporan keuangan

Digunakan untuk mempermudah dalam memahami informasi tentang laporan keuangan secara benar.

Menurut SAK EMKM bab 2 paragraf 1 dijelaskan bahwa tujuan dari laporan keuangan adalah menyediakan informasi posisi keuangan dan kinerja suatu entitas yang mempunyai manfaat yang besar bagi pengguna dalam pengambilan keputusan ekonomik oleh siapapun. Laporan keuangan menunjukkan pertanggungjawaban manajemen atas sumber daya yang dipercayakan padanya.

\section{SAK EMKM}

Menurut Agustina, dkk (2019:3), SAK EMKM merupakan pedoman bagi pelaku usaha UMKM untuk membuat laporan keuangan sederhana yang memiliki akses pendanaan yang semakin luas ke sektor perbankan agar terwujud UMKM yang maju, mandiri, dan modern. SAK EMKM dibuat melalui Dewan Standar Akuntansi Keuangan Ikatan Akuntan Indonesia (DSAK IAI) yang telah menerbitkan SAK Entitas Mikro, Kecil, dan Menengah (EMKM) yang telah disusun dan disahkan tahun 2016, namun efektif mulai diterapkan 1 Januari 2018 dan penerapan dini diperkenankan. Dibandingkan dengan pilar SAK lainnya yang 
ada di Indonesia, standar ini sengaja dibuat lebih sederhana dibandingkan dengan SAK umum berbasis IFRS dan SAK ETAP. Laporan keuangan EMKM telah dimuat dengan lengkap dalam SAK EMKM.

Dalam SAK EMKM bab 3 paragraf 9, Laporan keuangan minimum terdiri dari:

1. Laporan posisi keuangan pada akhir periode

Laporan posisi keuangan terdiri dari informasi mengenai asset, liabilitas dan ekuitas pada tanggal tertentu, dan disajikan dalam posisi keuangan. Laporan posisi keuangan entitas dapat mencangkup pos-pos berikut: Kas, piutang, persediaan, aset tetap, utang usaha, utang bank, dan ekuitas.

2. Laporan laba rugi selama periode

Menurut IAI (2016:11), bab 5 paragraf 1, entitas menyajikan laporan laba rugi merupakan kinerja keuangan entitas untuk suatu periode. Laporan laba rugi entitas dapat mencangkup pos-pos sebagai berikut: pendapatan, beban keuangan, dan beban pajak.

3. Catatan atas laporan keuangan, yang berisi tambahan dan rincian pos-pos tertentu yang relevan.

Menurut IAI (2016:13), bab 6 paragraf 2, catatan atas laporan keuangan memuat:

d. Suatu pernyataan bahwa laporan keuangan telah disusun sesuai dengan SAK EMKM.

e. Ikhtisar kebijakan akuntansi.

f. Informasi tambahan dan rincian pos tertentu yang menjelaskan transaksi penting dan material sehingga bermanfaat bagi pengguna untuk memahami laporan keuangan.

\section{Aplikasi Si Apik}

Menurut Bank Indonesia (2017), mengatakan “Aplikasi Si Apik adalah sebuah sistem pencatatan keuangan sederhana, cepat dan mudah berbasis android". Tujuan PTK Si Apik adalah menyediakan standar penyusunan laporan keuangan bagi UMK, menyediakan alat bantu bagi UMK dalam menyusun laporan keuangan, dan membantu lembaga keuangan dalam menganalisis kemampuan keuangan UMK. 


\section{UMKM}

UMKM merupakan badan usaha yang berkriteria usaha dalam lingkup kecil atau juga mikro yang usaha perdagangannya dikelola oleh perorangan. Peraturan mengenai UMKM didalam Undang-Undang Nomor 20 Tahun 2008 sebagai berikut:

1. Usaha Mikro

Merupakan badan usaha yang mempunyai kekayaan bersih dibawah Rp. 50.000.000,- per bulan belum termasuk bangunan dan tempat usaha. Omset tahunan maksimal Rp300.000.000,- (tiga ratus juta rupiah).

\section{Usaha Kecil}

Adalah sebuah usaha perorangan dengan kriteria mempunyai aset netto dibawah Rp. 300.000.000,- per tahun. Omset tahunan berkisar lebih dari Rp. 300.000.000,-(tiga ratus juta rupiah) dan maksimal Rp2.500.000.000,- (dua milyar lima ratus juta rupiah).

3. Usaha Menengah

Yaitu usaha yang laba bersihnya maksimal Rp. 500.000.000,- per bulan. Belum termasuk tanah juga bangunan. Omset tahunan lebih dari Rp. 2.500.000.000,(dua milyar lima ratus juta rupiah) dengan maksimal Rp50.000.000.000,00 (lima puluh milyar rupiah).

\section{METODE PENELITIAN}

Penelitian ini menggunakan pendekatan deskriptif kualitatif yang merupakan adanya hubungan simantis antar variabel yang sedang diteliti (Sarwono,2018) Tujuannya ialah untuk menjawab masalah yang dirumuskan dan agar peneliti mendapatkan makna hubungan variabel-variabel. Metode deskriptif bertujuan untuk memeriksa sebab-sebab dari suatu gejala tertentu dan mendeskripsikan apa yang ditemukan pada saat penelitian. Penelitian ini juga termasuk penelitian komparatif, karena penelitian ini juga ditujukan untuk membandingkan keberadaan suatu variabel atau lebih pada dua atau lebih sampel yang berbeda atau pada waktu yang berbeda (sugiyono,2014) 
Teknik pengumpulan data dengan wawancara dan observasi. Sedangkan untuk analisa data menggunakan model analisis interaktif terdiri dari tiga komponen yaitu reduksi data, penyajian data dan penarikan kesimpulan.

Jenis dan sumber data diperoleh dari data primer dari UMKM Pastellia BSD dengan teknik pengumpulan data wawancara dan observasi. Sedangkan untuk analisa data menggunakan model analisis interaktif terdiri dari tiga komponen yaitu reduksi data, penyajian data dan penarikan kesimpulan.

Penelitian ini dilakukan di UMKM Pastellia Intermoda Bumi Serpong Damai yang beralamat di Kios A3 No. 1-2 Pasar Modern Intermoda, Bumi Serpong Damai, Tangerang Selatan.

\section{HASIL DAN PEMBAHASAN}

Berdasarkan dari data yang diperoleh UMKM Pastellia Intermida BSD memiliki 3 laporan keuangan yaitu laporan posisi keuanagn / neraca, laporan laba rugi dan laporan arus kas. Pembuatan laporan keuangan dilakukan dengan menggunakan sistem manual (sederhana). Adapun siklus akuntansi yang dibuat oleh UMKM Pastellia Intermoda BSD adalah sebagai berikut:

1) Melakukan penyusunan laporan penjualan, pengelompokan biaya-biaya yang digunakan setiap bulannya.

2) Melakukan penjurnalan mulai dari jurnal umum dan jurnal penyesuaian setiap bulannya.

3) Menyusun buku besar, dan

4) Menyusun laporan keuangan, yaitu laporan laba rugi, laporan posisi keuangan, dan laporan arus kas akhir tahun (Desember 2018 dan Desember 2019).

\section{Laporan Posisi Keuangan UMKM Pastellia BSD}

Laporan posisi keuangan (Neraca) tahun 2018 UMKM Pastellia Intermoda Bumi Serpong Damai berada pada posisi yang baik yaitu memiliki aset dan modal yang seimbang tanpa adanya utang. Laporan posisi keuangan (Neraca) tahun 2019 UMKM Pastellia Intermoda Bumi Serpong Damai berada pada posisi yang baik yaitu memiliki aset dan modal yang seimbang tanpa adanya utang serta saldo laba yang meningkat. Laporan posisi keuangan (Neraca) tahun 2018 dan tahun 2019 dapat dilihat dalam lampiran. 
Berdasarkan hasil analisis Horizontal, terjadi peningkatan aset lancar sebesar 51.3\% yaitu Rp 240.825.703,-, penurunan dari aset tetap sebesar 7.9\% yaitu (Rp 36.875.000,-) dan total aset meningkat sebesar 21.8\% yaitu Rp 203.950.703.-Sedangkan total ekuitas meningkat sebesar 21.8\% Rp 203.950.703,- dan saldo laba meningkat sebesar $149.5 \%$ yaitu Rp 203.950.703,- yang menunjukkan hasil seimbang dan baik.

Berdasarkan hasil analisis Vertikal, total aset berasal dari peningkatan aset lancar yang masing-masing pada tahun 2018 sebesar 50.1\% yaitu Rp 469.054.250,, 2019 sebesar $62.3 \%$ yaitu Rp 709.879.953,- dan aset tetap yang masing-masing pada tahun 2018 sebesar 49.9\% yaitu Rp 467.343.750,- dan 2019 sebesar 37.7\% yaitu Rp 430.468.750,-. Dan total ekuitas berasal dari peningkatan modal yang masing-masing pada tahun 2018 sebesar 85.4\% yaitu Rp 800.000.000,- dan 2019 sebesar 70.2\% yaitu Rp 800.000.000,- dan saldo laba yang masing-masing pada tahun 2018 sebesar 14.6\% yaitu Rp 136.398.000,- dan 2019 sebesar 29.8\% 340.348.703,-. Perhitungan diambil dari masing-masing total penjumlahan.

\section{Laporan Laba Rugi UMKM Pastellia BSD}

Berisi informasi revenue dan expense pada perusahaan dalam jangka waktu tertentu. Laporan laba rugi tahun 2018 UMKM Pastellia Intermoda Bumi Serpong Damai tahun 2018 menghasilkan laba bersih sebesar Rp. 136.398.000. Yang artinya UMKM Pastellia Intermoda Bumi Serpong Damai mampu menjadi sebuah usaha yang berdiri sendiri dan mampu mengelola keuangannya dengan baik. Laporan laba rugi tahun 2019 UMKM Pastellia Intermoda Bumi Serpong Damai tahun 2018 menghasilkan laba bersih sebesar Rp. 340.348.703. Yang mana mengalami kenaikan sebesar $149.5 \%$ dari tahun lalu. Yang artinya UMKM Pastellia Intermoda Bumi Serpong Damai dapat mengelola usahanya mulai dari penjualan, pembelian, biaya-biaya dengan baik. Laporan laba rugi tahun 2018 dan tahun 2019 dapat dilihat dalam lampiran.

Berdasarkan hasil analisis horizontal, penjualan bersih meningkat $88.1 \%$ yaitu Rp 611.841.000,-. Penjualan meningkat sebesar $68.4 \%$ yaitu $\mathrm{Rp}$ 475.534.000,-. Laba kotor meningkat sebesar 68.4\%. yaitu Rp 277.097.150,- Total biaya meningkat sebesar $83.1 \%$ yaitu Rp127.400.525,-, peningkatan biaya produksi 
85.9\%, yaitu Rp 37.755.350,- biaya operasional 64.1\% yaitu $R p$ 11.977.300,-, biaya rusak $25 \%$ yaitu Rp 2.269.125,-, biaya gaji $122.2 \%$ yaitu $66.000 .000,-$, biaya penyusutan $33.3 \%$ yaitu Rp 9.218.750,-. Sedangkan laba bersih meningkat $149.5 \%$ yaitu Rp 203.950.703 yang menunjukkan hasil menguntungkan

Berdasarkan hasil analisis vertikal, Harga pokok penjualan pada tahun 2018 sebesar 58.3\% yaitu Rp 404.974.925,- dan tahun 2019 sebesar 52.2\% yaitu Rp 682.072.075. Total biaya pada tahun 2018 sebesar 22.1\% yaitu Rp 153.351.575,dan tahun 2019 sebesar 21.5\% yaitu Rp 280.752.100,-. Laba Bersih pada tahun 2018 sebesar 19.6\% yaitu Rp 136.398.000,- dan 2019 sebesar 26\% yaitu Rp 340.348.703,-. Perhitungan yang diambil dari persentase penjualan bersih.

\section{Laporan Arus Kas UMKM Pastellia BSD}

Menginformasikan kegiatan-kegiatan yang berhubungan dengan keluar masuknya kas dalam suatu perusahaan. Laporan arus kas tahun 2018 Pastellia Intermoda Bumi Serpong Damai berada dalam keadaan bagus karena memiliki aktivitas operasi dan aktivitas pendanaan yang positif yang artinya memiliki sumber kas yang cukup. Laporan arus kas tahun 2019 Pastellia Intermoda Bumi Serpong Damai berada dalam keadaan bagus karena memiliki aktivitas operasi dan aktivitas pendanaan yang positif yang artinya memiliki sumber kas yang cukup. Sedangkan kegiatan investasi bernilai negative yang artinya perusahaan tidak bergantung dengan investor. Laporan arus kas tahun 2018 dan tahun 2019 dapat dilihat dalam lampiran.

Berdasarkan hasil analisis horizontal, kas dan setara kas meningkat sebesar 49.7\% yaitu Rp 230.526.950,-. Peningkatan arus kas dari aktivitas operasi sebesar 40.8\% yaitu $\mathrm{Rp}$ 66.752.778,- dan penurunan arus kas dari aktivitas pendanaan sebesar $42.1 \%$ yaitu (Rp 336.473.050) yang menunjukkan perusahaan memiliki kas yang baik.

Arus kas dari aktivitas operasi pada tahun 2018 sebesar $35.3 \%$ yaitu Rp 163.526.950,- dan tahun 2019 sebesar 33.2\% yaitu Rp 230.279.728,-. Arus kas dari aktivitas pendanaa tahun 2018 sebesar 172.6\% yaitu Rp 800.000.000,- dan tahun 2019 sebesar $66.8 \%$ yaitu Rp 463.526.950,-. Perhitungan persentase diambil dari total kas dan setara kas. 


\section{Laporan Posisi Keuangan Versi Si Apik}

Laporan posisi keuangan (Neraca) tahun 2018 UMKM Pastellia Intermoda Bumi Serpong Damai menggunakan aplikasi Siapik berada pada posisi yang baik yaitu memiliki aset dan modal yang seimbang tanpa adanya utang serta saldo laba yang meningkat. Laporan posisi keuangan (Neraca) tahun 2019 UMKM Pastellia Intermoda Bumi Serpong Damai menggunakan aplikasi Siapik berada pada posisi yang baik yaitu memiliki aset dan modal yang seimbang tanpa adanya utang serta saldo laba yang meningkat. Laporan posisi keuangan tahun 2018 dan tahun 2019 versi Si apik dapat dilihat dalam lampiran.

\section{Laporan Laba Rugi Versi Si Apik}

Laporan laba rugi tahun 2018 UMKM Pastellia Intermoda Bumi Serpong Damai melalui aplikasi Siapik menghasilkan laba bersih sebesar Rp. 122.700.083. Yang artinya UMKM Pastellia Intermoda Bumi Serpong Damai dapat mengelola usahanya dengan baik dan laporan keuangannya dapat diterapkan dalam Aplikasi Siapik. Laporan laba rugi tahun 2019 UMKM Pastellia Intermoda Bumi Serpong Damai melalui aplikasi Siapik menghasilkan laba bersih sebesar Rp. 307.275.785. Mengalami kenaikan $<100 \%$ dari laba bersih tahun lalu. Yang artinya UMKM Pastellia Intermoda Bumi Serpong Damai dapat mengelola usahanya dengan baik dan laporan keuangannya dapat diterapkan dalam Aplikasi Siapik. Laporan laba rugi tahun 2018 dan tahun 2019 versi Si apik dapat dilihat dalam lampiran.

\section{Laporan Arus Kas Versi Si Apik}

Laporan arus kas tahun 2018 Pastellia Intermoda Bumi Serpong Damai berada dalam keadaan bagus karena memiliki aktivitas yang bernilai positif yang artinya memiliki sumber kas yang cukup. Laporan arus kas tahun 2019 Pastellia Intermoda Bumi Serpong Damai yang menggunakan aplikasi Siapik berada dalam keadaan bagus karena memiliki aktivitas yang bernilai positif yang artinya memiliki sumber kas yang cukup. Dan mengalami kenaikan dalam kegiatan usahanya. Laporan arus kas tahun 2018 dan tahun 2019 versi Si apik dapat dilihat dalam lampiran. 


\section{Perbedaan Laporan Keuangan UMKM Pastellia Intermoda BSD dengan Aplikasi Si Apik}

\section{Laporan Posisi Keuangan}

Perbedaan yang terjadi dalam laporan keuangan yang disusun sendiri oleh UMKM Pastellia Intermoda Bumi Serpong Damai dengan laporan keuangan yang disusun menggunakan aplikasi Siapik terletak pada perhitungan penyusutan aset tetap yang dihasilkan. Sehingga berpengaruh pada setiap laporan keuangan yang ada. Mulai dari laporan keuangan bulanan hingga laporan keuangan tahunan. Begitu pula dengan analisa horizontal dan analisis vertical juga terpengaruh dengan adanya perbedaan perhitungan penyusutan aset tetap tersebut. Pada laporan posisi keuangan komparatif dan laporan laba rugi komparatif komparatif baik dari sisi analisis laporan yang dibuat oleh UMKM Pastellia Intermoda Bumi Serpong Damai ataupun dari sisi analisis laporan keuangan dari aplikasi Siapik.

Pada laporan posisi keuangan tahun 2018 terdapat selisih pada penyusutan aset tetap sebesar Rp 13.697.917,- yang berasal dari laporan keuangan UMKM Pastellia Intermoda Bsd sebesar Rp 936.398.000,- dan laporan keuangan dalam aplikasi siapik sebesar Rp 922.700.083,-. Tahun 2019 terdapat selisih pada penyusutan aset tetap sebesar Rp 33.072.918,- yang berasal dari laporan keuangan UMKM Pastellia Intermoda Bsd sebesar Rp 1.140.348.703,- dan laporan keuangan dalam aplikasi siapik sebesar Rp 1.107.275.785,-. Pada laporan laba rugi tahun 2018 terdapat selisih 13.697.917,- yang berasal dari laporan keuangan UMKM Pastellia Intermoda Bsd sebesar Rp 136.398.000,- dan laporan keuangan dalam aplikasi siapik sebesar Rp 122.700.083,-- Tahun 2019 terdapat selisih sebesar Rp 33.072.918,- yang berasal dari laporan keuangan UMKM Pastellia Intermoda Bsd sebesar Rp 340.348.703,- dan laporan keuangan dalam aplikasi siapik sebesar Rp 307.275.785,-. Selisih antara tahun 2018 dan 2019 yaitu sebesar Rp 33.072.918,-.

\section{Laporan Laba Rugi}

Pada laporan laba rugi tahun 2018 perbedaan terletak pada beban penyusutan sebesar Rp 13.697.917,- berasal dari perbedaan perhitungan penyusutan 
selama 9 bulan mulai dari april sampai dengan desember sebesar Rp 41.354.167,-dan $\mathrm{Rp}$ 27.656.250.-. Sehingga mempengaruhi laba yang diperoleh yaitu $\mathrm{Rp}$ 122.700.083,- dan Rp 136.398.000,- yang mempunyai selisih sebesar Rp 13.697.917,--.

Pada laporan laba rugi tahun 2019 perbedaan terletak pada beban penyusutan sebesar Rp 19.375.000,- berasal dari perbedaan perhitungan penyusutan selama 12 bulan mulai dari januari sampai dengan desember sebesar $\mathrm{Rp}$ 56.250.000,- dan Rp 36.875.000.-. Sehingga mempengaruhi laba yang diperoleh yaitu Rp 307.275.785,- dan Rp 340.348.703,- yang mempunyai selisih sebesar Rp 33.072.918,-.

\section{Penyajian Laporan Keuangan yang diterapkan UMKM Pastellia Intermoda Bumi Serpong Damai dan kesesuaiaanya dengan SAK EMKM.}

Dalam Pastellia Intermoda Bumi Serpong Damai memiliki 3 laporan keuangan yaitu:

1. Laporan Posisi Keuangan (Neraca)

2. Laporan Laba Rugi

3. Laporan Arus Kas

Dari uraian diatas dapat digambarakan bahwa laporan keuangan UMKM Pastellia Intermoda Bumi Serpong Damai belum sesuai dengan SAK EMKM karena UMKM Pastellia Intermoda Bumi Serpong Damai hanya memiliki 3 jenis laporan keuangan dan tidak membuat catatan atas laporan keuangan (CALK)

\section{PENUTUP}

Penulis ingin menerapkan sistem pencatatan laporan keuangan berbasis android Siapik serta mengimplementasikannya berdasarkan SAK EMKM pada UMKM Pastellia Intermoda BSD dengan kesimpulan:

1. Laporan keuangan UMKM Pastellia Intermoda Bumi Serpong Damai masih melakukan pencatatan laporan keuangan yang bersifat manual. Laporan keuangan UMKM Pastellia Intermoda Bumi Serpong Damai dalam penyusunannya belum berdasarkan SAK EMKM yang berlaku karena belum adanya catatan laporan keuangan yang dihasilkan oleh UMKM tersebut. 
2. Jenis-jenis laporan keuangan yang dihasilkan oleh UMKM Pastellia Intermoda Bumi Serpong Damai yaitu sebagai berikut:
a. Laporan Neraca
b. Laporan laba rugi
c. Laporan arus kas

3. Laporan keuangan UMKM Pastellia Intermoda Bumi Serpong Damai dengan menggunakan aplikasi $\mathrm{Si}$ apik untuk memudahkan penyusunan laporan keuangan. Jenis-jenis laporan keuangan UMKM Pastellia Intermoda Bumi Serpong Damai yang dihasilkan dalam melalui Aplikasi Siapik yaitu sebagai berikut:
a. Laporan posisi keuangan
b. Laporan laba rugi
c. Laporan arus kas

4. Perbedaan laporan keuangan yang dihasilkan oleh UMKM Pastellia Intermoda Bumi Serpong dengan aplikasi Si Apik adalah pada laporan posisi keuangan \& laporan laba rugi terkait penyusutan aset tetap.

\section{DAFTAR PUSTAKA}

Agustina, Y., Sri Setianingsih \& Yudy Dwi Santoso. 2019. Pelatihan Penyusunan Laporan Keuangan Bagi Entitas Mikro, Kecil, dan Menengah Bidang Usaha Dagang pada UMKM Binaan Pusat Inkubasi Bisnis Syariah Majelis Ulama Indonesia. Intervensi Komunitas: Jurnal Pengabdian Masyarakat, Vol 1(2714691X), 13.

Agustina, Y., Sri Setianingsih \& Henny Mulyati. 2021. Pelatihan Penyusunan Laporan Keuangan Dengan Menggunakan aplikasi Si Apik pada UMKM. Intervensi Komunitas: Jurnal Pengabdian Masyarakat, Vol 1(2714-691X), Vol 2 no. 2

Amatullah, D. dkk. 2019. Analisis Penyusunan Laporan Keuangan UMKM Batik Jumput Dahlia Berdasarkan SAK-EMKM. Balance, Vol 16.

Bank Indonesia. 2017. Sistem Informasi Aplikasi Pencatatan Informasi Keuangan. [www document] (http://psp.pertanian.go.id/assets/file/2017/Pelatihan _SIAPIK_Pesantren_publish_reduce.pdf).

Hery. 2015. Pengantar Akuntansi Comprehensive Edition. Jakarta: PT Grasindo. 2015. Praktis Menyusun Laporan Keuangan. Jakarta: PT Grasindo. 
Huda, F. A. 2017. Pengertian dan Definisi Kajian Pustaka. (http://fatkhan.web.id/pengertian-dan-definisi-kajian-pustakal, diakses 29 Juli 2017).

Ikatan Akuntansi Indonesia. 2016. Standar Akuntansi Keuangan Entitas Mikro, Kecil dan Menengah. Jakarta: Ikatan Akuntansi Indonesia (IAI).

Judianto, R., Ismunawan \& Arif Nugroho. 2018. Implementasi Penyusunan Laporan Keuangan UMKM Berdasarkan Standar Akuntansi Keuangan Entitas Mikro Kecil dan Menengah (SAK-EMKM) Pada UKM Davin Decor Surakarta. JAB, Vol 4 No.(2502-3497).

Mukhzarudfa, \& Kusumastuti, R. 2019. Praktik Akuntansi Keuangan Usaha Perajin Batik di Kecamatan Pelayangan, Kota Jambi. Karya Abdi Masyarakat, Vol 3 No.(2580-2178).

Pastellia. 2020. Laporan Keuangan. Tangerang Selatan

Putra, Y. M. 2018. Pemetaan Penerapan Standar Akuntansi Keuangan EMKM pada UMKM di Kota Tangerang Selatan. Komunikasi Ilmiah Akuntansi Dan Perpajakan, Vol 11 No.(2622-1950).

Rahmawati, D. 2017. Implementasi Program Kerja Pemberdayaan dan Kesejahteraan Keluarga dalam Pemberdayaan Ekonomi Rumah Tangga Muslim di Kabupaten Lampung Tengah. Program Magister Pengembangan Masyarakat Islam. Lampung: Universitas Islam Negeri Raden Intan Lampung.

Sarwono, J. 2018. Metode Penelitian Kuantitatif dan Kualitatif Edisi 2. Yogyakarta: Suluh Media.

Sugiono.2014. Metode Penelitian Kombinasi (Mixed Method). Bandung : Penerbit Alfabeta.

Sholikin, A., \& Ade Setiawan. 2018. Kesiapan UMKM Terhadap Implementasi SAK EMKM (Studi UMKM Di Kabupaten Blora). Jurnal of Islamic Finance and Accounting, Vol 1 No.(2615-1782).

Tajibu, M. J., Bachtiar Mustari \& Baso Siswadarma. 2019. Peningkatan Akseksibilitas Terhadap Perbankan Melalui Pelatihan Penyusunan Laporan Keuangan Bagi UMKM di Kabupaten Bone. Journal of Management and Business, Vol 3 No.(2598-8301).

Undang-undang Nomor 20 tahun 2008 tentang Usaha Mikro Kecil dan Menengah.

Wiratama, B. dkk. 2019. Penerapan Aplikasi Keuangan Berbasis Android "Si Apik" pada Penyusunan Laporan Keuangan UMKM Biofarmakaka Desa Limbangan Kendal. Penerapan Teknologi Dan Pembelajaran.

Zamzami, F. 2017. Akuntansi Pengantar 1. Jakarta: Grasindo dengan Gadjah Mada University Press. 


\section{Lampiran}

Tabel 1. Laporan Posisi Keuangan UMKM Pastellia Intermoda BSD

pastellia

Laporan kosss kevangan

Per 31 Desember 2018

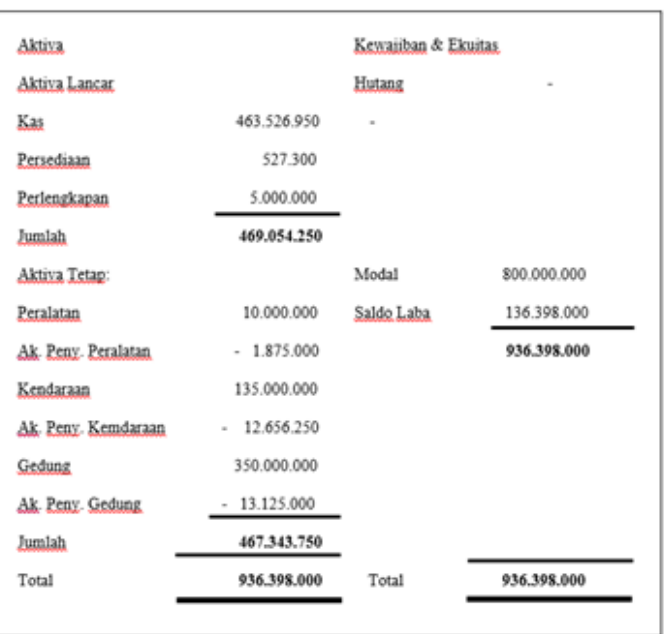

pastellia

Laporan Posisi Keuangan

Per 31 Desember 2019

\begin{tabular}{|c|c|c|c|}
\hline Actixa & & \multicolumn{2}{|c|}{ Kewajiban \& Ekuitas } \\
\hline Aktiva Lancar. & & Hutang & \\
\hline Kas & 478.506 .178 & - & \\
\hline Bank BCA & 215.300 .500 & & \\
\hline Rercediaan & 11.073 .275 & & \\
\hline Perlengkapan & 5.000 .000 & & \\
\hline Jumlah & 709.879 .953 & & \\
\hline Aktiva Tetap: & & Modal & 800.000 .000 \\
\hline Reralatan & 10.000 .000 & Salde Laba & 340.348 .703 \\
\hline Ak Reny. Reralatan & $-\quad 4.375 .000$ & & 1.140 .348 .703 \\
\hline Kendaraan & 135.000 .000 & & \\
\hline Ak Peny. Kemdaraan & - $\quad 29.531 .250$ & & \\
\hline Gedung & 350.000 .000 & & \\
\hline Ak Reny Gedung & 30.625 .000 & & \\
\hline Jumlah & 430.468 .750 & & \\
\hline Total & 1.140 .348 .703 & Total & 1.140 .348 .703 \\
\hline
\end{tabular}

Tabel 2. Laporan Laba Rugi UMKM pastellia

Laporan Laba Ruzi

Per 31 Deiember 2018

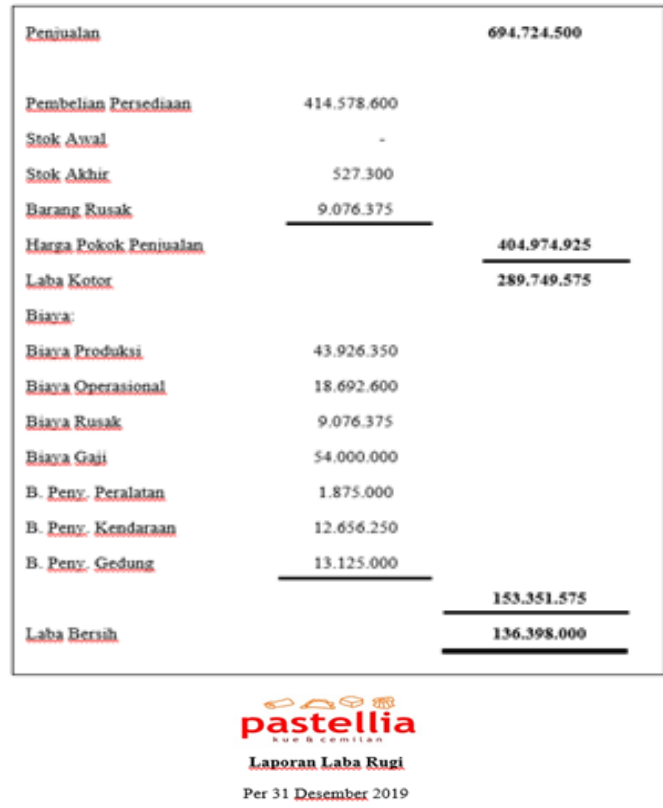

\begin{tabular}{|c|c|c|}
\hline Penjualan & & 1.170 .258 .500 \\
\hline Pembelian & 704.973 .550 & \\
\hline Stok Awal & 527.300 & \\
\hline Stok Akhir & 11.073 .275 & \\
\hline Barang Rusak & 11.345 .500 & \\
\hline Harga Pokok Penjualan & & 682.072 .075 \\
\hline Laba Kotox & & 488.176 .425 \\
\hline \multicolumn{3}{|l|}{ Biaya: } \\
\hline Biaya Produksi & 81.861 .700 & \\
\hline Biava Operasional & 30.669 .900 & \\
\hline Biaya Rusak & 11.345 .500 & \\
\hline Biaya Gaaii & 120.000 .000 & \\
\hline B. Peny, Peralatan & 2.500 .000 & \\
\hline B. Peny. Kendaraan & 16.875 .000 & \\
\hline \multirow[t]{2}{*}{ B. Peny Gedung } & 17.500 .000 & \\
\hline & & 280.752 .100 \\
\hline $\mathrm{PPh} 25$ & & 3.473 .623 \\
\hline Laba Bersih & & 203.950 .703 \\
\hline
\end{tabular}


Tabel 3. Laporan Arus Kas UMKM

$$
\text { pastellia }
$$$$
\text { Per } 31 \text { Desember } 2018
$$

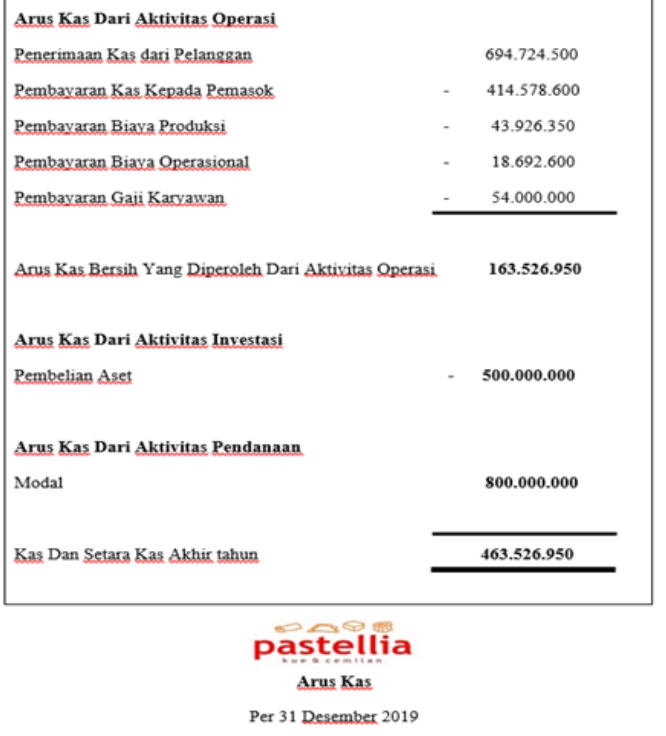

in
pastellia

Tabel 4. format laporan posisi keuangan

\begin{tabular}{|c|c|}
\hline \multicolumn{2}{|c|}{ Per Tahun (Desember - 2018) } \\
\hline Jumlah Aset & Rp922,700,083.33 \\
\hline $\begin{array}{l}\text { Jumlah Kewajiban, Modal } \\
\text { dan Saldo Laba }\end{array}$ & Rp922,700,083.33 \\
\hline ASET & Rp922,700,083.33 人 \\
\hline Kas & Rp463,526,950.00 \\
\hline Persediaan & Rp527,300.00 \\
\hline Aset Tetap & Rp495,000,000.00 \\
\hline Aset Lain & Rp5,000,000.00 \\
\hline Akumulasi Penyusutan & Rp-41,354,166.67 \\
\hline KEWAJIBAN & Rp0.00 へ \\
\hline MODAL \& Saldo Laba & Rp922,700,083.33 へ \\
\hline Modal & Rp800,000,000.00 \\
\hline Saldo Laba & Rp122,700,083.33 \\
\hline \multicolumn{2}{|c|}{ Per Tahun (Desember - 2019) } \\
\hline Jumlah Aset & Rp1,107,275,785.33 \\
\hline $\begin{array}{l}\text { Jumlah Kewajiban, Modal } \\
\text { dan Saldo Laba }\end{array}$ & Rp1,107,275,785.33 \\
\hline ASET & Rp1,107,275,785.33 人 \\
\hline Kas & Rp478,506,177.00 \\
\hline Tabungan & Rp215,300,500.00 \\
\hline Persediaan & Rp11,073,275.00 \\
\hline Aset Tetap & Rp495,000,000.00 \\
\hline Aset Lain & Rp5,000,000.00 \\
\hline Akumulasi Penyusutan & Rp-97,604,166.67 \\
\hline KEWAJIBAN & Rp0.00 へ \\
\hline MODAL \& Saldo Laba & Rp1,107,275,785.33 人 \\
\hline Modal & Rp800,000,000.00 \\
\hline Saldo Laba & Rp307,275,785.33 \\
\hline
\end{tabular}
SI APIK UMKM 
Tabel 5. Laporan Laba Rugi Si Apik

\begin{tabular}{|c|c|}
\hline Saldo Laba (Rugi) Akhir & Rp122,700,083.33 \\
\hline PENGHASILAN & Rp694,724,500.00 人 \\
\hline Penjualan & Rp694,724,500.00 \\
\hline Penghasilan Lain & Rpo.oo \\
\hline BEBAN & $($ Rp572,024,416.67) 人 \\
\hline Beban Persediaan & Rp404,974,925.00 \\
\hline Beban Tenaga Kerja & Rp54,000,000.00 \\
\hline Beban Sewa & Rpo.oo \\
\hline Beban Transportasi & Rpo.oo \\
\hline Beban Bahan Bakar & Rpo.oo \\
\hline Beban Listrik & Rpo.oo \\
\hline Beban Air & Rpo.oo \\
\hline Beban Telepon & Rpo.oo \\
\hline Beban Penyusutan & Rp41,354,166.67 \\
\hline Beban Umum dan Administrasi & Rpo.oo \\
\hline Beban Lain & Rp71,695,325.00 \\
\hline
\end{tabular}

\begin{tabular}{|c|c|}
\hline Saldo Laba (Rugi) Akhir & Rp307,275,785.33 \\
\hline PENGHASILAN & Rp1,170,258,500.00 人 \\
\hline Penjualan & Rp1,170,258,500.00 \\
\hline Penghasilan Lain & Rpo.00 \\
\hline BEBAN & $($ Rp985,682,798.00) 人 \\
\hline Beban Persediaan & Rp682,082,075.00 \\
\hline Beban Tenaga Kerja & Rp120,000,000.00 \\
\hline Beban Sewa & Rpo.00 \\
\hline Beban Transportasi & Rpo.oo \\
\hline Beban Bahan Bakar & Rpo.00 \\
\hline Beban Listrik & Rpo.o0 \\
\hline Beban Air & Rp0.00 \\
\hline Beban Telepon & RpO.00 \\
\hline Beban Penyusutan & Rp56,250,000.00 \\
\hline Beban Umum dan Administrasi & Rpo.oo \\
\hline Beban Lain & Rp127,350,723.00 \\
\hline
\end{tabular}

Tabel 6. Laporan Arus Kas Si Apik

\begin{tabular}{|lr|}
\hline \multicolumn{2}{|l}{ Periode: Tahun (Desember - 2018) } \\
$\begin{array}{l}\text { Kenaikan(Penurunan) Kas dan Setara } \\
\text { Kas }\end{array}$ & Rp26,855,000.00 \\
$\begin{array}{l}\text { Saldo Awal Setara Kas } \\
\text { Saldo Akhir Setara Kas }\end{array}$ & Rp436,671,950.00 \\
\hline $\begin{array}{l}\text { PENERIMAAN KAS DAN SETARA } \\
\text { KAS }\end{array}$ & RP99,880,000.00 \\
\hline
\end{tabular}

Kegiatan Usaha

Rp99,880,000.00

Penerimaan Pinjaman

Rpo.00

Tambahan Modal

Rpo.0o

PENGELUARAN KAS DAN
SETARA KAS

Kegiatan Usaha

(Rp73,025,000.00)

Pelunasan Pinjaman

(Rpo.00)

Penarikan Oleh Pemilik (Rpo.oo)

\begin{tabular}{|ll|}
\hline \multicolumn{2}{|c|}{ Periode: Tahun (Desember - 2019) } \\
\hline $\begin{array}{l}\text { Kenaikan(Penurunan) Kas dan Setara } \\
\text { Kas }\end{array}$ & Rp23,753,550.00 \\
\hline Saldo Awal Setara Kas & Rp670,053,127.00 \\
\hline Saldo Akhir Setara Kas & Rp693,806,677.00
\end{tabular}
PENERIMAAN KAS DAN SETARA RP103,647,500.00
KAS

Kegiatan Usaha

Rp103,647,500.00

Penerimaan Pinjaman

Rp0.00

Tambahan Modal Rp0.00

\begin{tabular}{l}
$\begin{array}{l}\text { PENGELUARAN KAS DAN } \\
\text { SETARA KAS }\end{array}$ \\
\hline
\end{tabular}

Kegiatan Usaha

(Rp79,893,950.00)

Pelunasan Pinjaman

(Rp0.00)

Penarikan Oleh Pemilik

(Rp0.00) 
Tabel 7. Perbedaan Laporan Posisi Keuangan

\begin{tabular}{|c|c|c|c|}
\hline & \multicolumn{2}{|c|}{$\begin{array}{c}\text { Paste IIia } \\
\text { Laporan Posisi Keuangan Kemparatif } \\
31 \text { Desember } 2019 \\
\text { (Dalam Rupiah) }\end{array}$} & \\
\hline & Pastellia & Slagik & $\begin{array}{l}\text { Kenaikan (Renuruana) } \\
\text { Jumlah }\end{array}$ \\
\hline \multicolumn{4}{|l|}{ Aset } \\
\hline 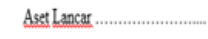 & 709.879 .953 & 704.054 .250 & 5.000 .000 \\
\hline 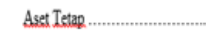 & 430.468 .750 & 402.395 .833 & 28.072 .917 \\
\hline Total Aset ............................. & 1.140 .348 .703 & 1.107 .275 .785 & 33.072 .917 \\
\hline \multicolumn{4}{|l|}{ Ekuitas } \\
\hline 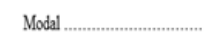 & 800.000 .000 & 800.000 .000 & \\
\hline Saldo Laba & 340.348 .703 & 307.275 .785 & 33.072 .918 \\
\hline 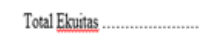 & 1.140 .348 .703 & 1.107 .275 .785 & 33.072 .918 \\
\hline & $\begin{array}{r}\text { Past } \\
\text { Laporan Posisi } K= \\
31 \text { Deser } \\
\text { (Dalam }\end{array}$ & $\begin{array}{l}\text { IIia } \\
2018 \\
\text { jiah) }\end{array}$ & \\
\hline & Pastellia & Siagik & $\begin{array}{l}\text { Kenaikan (Penunuan) } \\
\text { Jumlah }\end{array}$ \\
\hline \multicolumn{4}{|l|}{ dset } \\
\hline Aset Lancar ......................... & 469.054 .250 & 464.054 .250 & 5.000 .000 \\
\hline Aset Tetap & 467.343 .750 & 458.645 .833 & 8.697 .917 \\
\hline 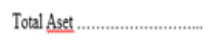 & 936.398 .000 & 922.700 .083 & 13.697 .917 \\
\hline \multicolumn{4}{|l|}{ Ekuitas } \\
\hline Modal ............................ & 800.000 .000 & 800.000 .000 & \\
\hline 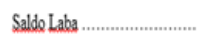 & 136.398 .000 & 122.700 .083 & 13.697 .917 \\
\hline 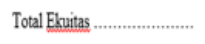 & 936.398 .000 & 922.700 .083 & 13.697 .917 \\
\hline
\end{tabular}

Tabel 8. Perbedaan Laporan Laba Rugi

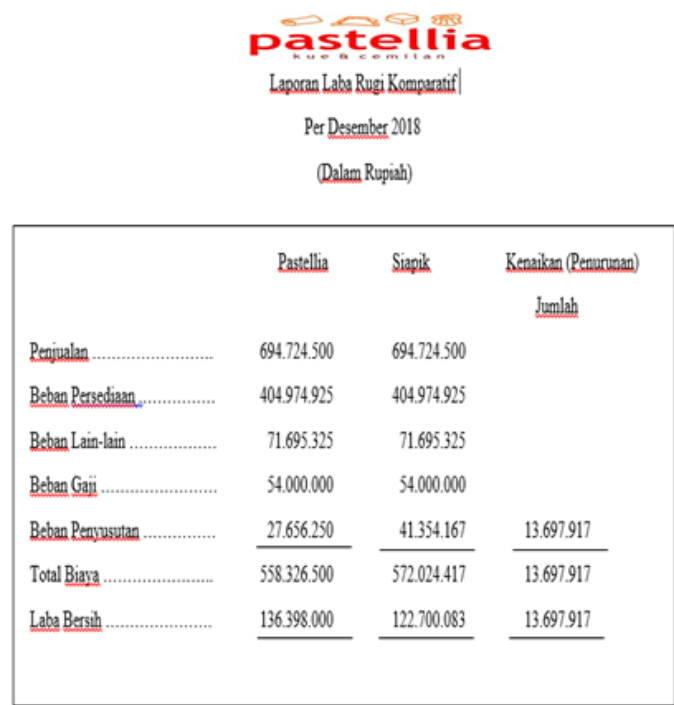

\begin{tabular}{|c|c|c|c|}
\hline \multicolumn{4}{|c|}{$\begin{array}{c}\text { Pastelía } \\
\text { Laporan Laba Rugi Kompartif } \\
\text { Per Desember } 2019 \\
\text { (Dalam Rupiah) }\end{array}$} \\
\hline & Pastellia & Siagik & $\begin{array}{l}\text { Kenaikan (Peaurousan) } \\
\text { Jumlah }\end{array}$ \\
\hline Laba Tahun Lalu ................ & 136398.000 & 1227000083 & \\
\hline Penjualan ............................. & 1.170 .258 .500 & 1.170 .258 .500 & \\
\hline Beban Persediaan, & 682.072 .075 & 682082.075 & \\
\hline Beban Lain-Jain ............... & 127.350 .723 & 127350.723 & \\
\hline 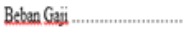 & 120.000 .000 & 120.000 .000 & \\
\hline Beban Penvusutan ................ & 36.875 .000 & 56.250 .000 & 19.375 .000 \\
\hline Total Biaza ............... & 966.297 .798 & 985.682 .798 & 19.375 .000 \\
\hline Laba Bersh & 340.348 .703 & 307.275 .785 & 33.072 .918 \\
\hline
\end{tabular}

